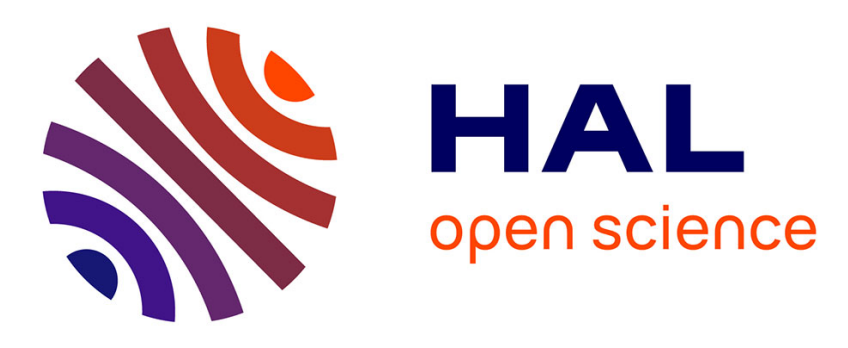

\title{
Importance of dimensional changes on glycolytic metabolism during growth
}

\author{
Allison Diry, Sébastien Ratel, Joffrey Bardin, Neil Armstrong, Quentin de \\ Larochelambert, Claire Thomas, Hugo Maciejewski
}

\section{To cite this version:}

Allison Diry, Sébastien Ratel, Joffrey Bardin, Neil Armstrong, Quentin de Larochelambert, et al.. Importance of dimensional changes on glycolytic metabolism during growth. European Journal of Applied Physiology, 2020, 120, pp.2137-2146. 10.1007/s00421-020-04436-z . hal-02935264

\section{HAL Id: hal-02935264 https: / hal-insep.archives-ouvertes.fr/hal-02935264}

Submitted on 10 Sep 2020

HAL is a multi-disciplinary open access archive for the deposit and dissemination of scientific research documents, whether they are published or not. The documents may come from teaching and research institutions in France or abroad, or from public or private research centers.
L'archive ouverte pluridisciplinaire HAL, est destinée au dépôt et à la diffusion de documents scientifiques de niveau recherche, publiés ou non, émanant des établissements d'enseignement et de recherche français ou étrangers, des laboratoires publics ou privés. 
Original article

2

3 Importance of dimensional changes on glycolytic metabolism during growth

4

5 Allison Diry ${ }^{1,2}$, Sébastien Ratel ${ }^{3 *}$, Joffrey Bardin ${ }^{2}$, Neil Armstrong ${ }^{4}$, Quentin Delaroche Lambert ${ }^{5}$, Claire

6 Thomas $^{6^{*}}$, Hugo Maciejewski ${ }^{1,6^{*}}$

7

$8 \quad{ }^{1}$ French Rowing Federation, Nogent-sur-Marne, France.

$9{ }^{2}$ French Institute of Sport (INSEP), Research Department, Laboratory Sport, Expertise, and Performance - EA

107370 , Paris, France.

$11{ }^{3}$ AME2P - EA 3533, Clermont-Auvergne University, Clermont-Ferrand, France.

$12{ }^{4}$ Children's Health and Exercise Research Centre, University of Exeter, Exeter, United Kingdom.

$13{ }^{5}$ French Institute of Sport (INSEP), IRMES (Institut de Recherche bioMédicale et d'Épidémiologie du Sport) 14 EA 7329, Paris, France.

$15{ }^{6}$ LBEPS - University of Évry Val d'Essonne, IRBA - Université Paris Saclay Évry, France.

$16 *$ These authors contributed equally to this work.

17

18 ORCID Allison Diry: 0000-0003-2425-6169

19 ORCID Sébastien Ratel: 0000-0003-2471-158X

20 ORCID Neil Armstrong: 0000-0002-3086-629X

21 ORCID Hugo Maciejewski: 0000-0003-0686-921X

22

23 Running title: Glycolytic metabolism during growth

24

25

Corresponding author: Hugo Maciejewski

French Rowing Federation

27

17, boulevard de la Marne

28

94130 Nogent-sur-Marne

29

hugo.maciejewski@ffaviron.fr 
Glycolytic metabolism during growth

AUTHOR CONTRIBUTION STATEMENT

$31 \mathrm{AD}, \mathrm{SR}, \mathrm{CT}$, and HM conceived and designed research. AD, SR, JB, CT and HM conducted experiments and

32 collected data. AD, SR, QDL and HM analysed data. AD, SR, NA, CT and HM wrote the manuscript. AD, SR,

$33 \mathrm{JB}, \mathrm{QDL}, \mathrm{NA}, \mathrm{CT}$ and HM provided critical revisions important for intellectual content of the finished

34 manuscript, approved the final version of the manuscript, and agree to be accountable for all aspects of the work

35 in ensuring that questions related to the accuracy or integrity of any part of the work are appropriately

36 investigated and resolved. All persons designated as authors qualify for authorship, and all those who qualify for

37 authorship are listed.

38

CONSENT TO PARTICIPATE

40 Written informed consent was obtained from all individual included in the study, and from their parents or legal 41 guardians.

42

CONSENT TO PUBLISH

44 Participants (and their parents or legal guardians) signed informed consent regarding publishing their data.

45

46

\section{ACKNOWLEDGEMENTS}

47 The authors thank Matthieu Chapron, Adrien Druenne, Nathalie Capelle, all rowers for their participation, and the

48 Club of Aviron Marne Joinville for their welcome, technical assistance and availability during this study.

\section{CONFLICT OF INTEREST}

51 The authors declare that they have no conflict of interest. 


\section{Glycolytic metabolism during growth}

\section{ABSTRACT}

Purpose: The aim of the present study was to investigate (i) how glycolytic metabolism assessed by accumulated oxygen deficit $\left(\mathrm{AOD}_{\text {gly }}\right)$ and blood metabolic responses (lactate and $\left.\mathrm{pH}\right)$ resulting from highintensity exercise change during growth, and (ii) how lean body mass (LBM) influences $\mathrm{AOD}_{\text {gly }}$ and its relationship with blood markers.

Methods: Thirty-six 11- to 17-year-olds performed a 60-s all-out test on a rowing ergometer. Allometric modelling was used to investigate the influence of LBM and LBM + maturity offset (MO) on $\mathrm{AOD}_{\text {gly }}$ and its relationship with the extreme post-exercise blood values of lactate ([La $\left.]_{\max }\right)$ and $\mathrm{pH}\left(\mathrm{pH}_{\min }\right)$ obtained during the recovery period.

Results: $\mathrm{AOD}_{\mathrm{gly}}$ and $[\mathrm{La}]_{\max }$ increased while $\mathrm{pH}_{\min }$ decreased linearly with $\mathrm{LBM}$ and $\mathrm{MO}\left(\mathrm{r}^{2}=0.46\right.$ to $0.72, \mathrm{p}<$ $0.001)$. Moreover, $\mathrm{AOD}_{\mathrm{gly}}$ was positively correlated to $[\mathrm{La}]_{\max }\left(\mathrm{r}^{2}=0.75, \mathrm{p}<0.001\right)$ and negatively correlated to $\mathrm{pH}_{\min }\left(\mathrm{r}^{2}=0.77, \mathrm{p}<0.001\right)$. When $\mathrm{AOD}_{\text {gly }}$ was scaled for LBM, the coefficients of the relationships with blood markers drastically decreased by three to four times $\left([\mathrm{La}]_{\max }: \mathrm{r}^{2}=0.24, \mathrm{p}=0.002 ; \mathrm{pH}_{\min }: \mathrm{r}^{2}=0.30, \mathrm{p}<0.001\right)$. Furthermore, by scaling $\mathrm{AOD}_{\text {gly }}$ for LBM + MO, the correlation coefficients with blood markers became even lower $\left([\mathrm{La}]_{\max }: \mathrm{r}^{2}=0.12, \mathrm{p}=0.037 ; \mathrm{pH}_{\min }: \mathrm{r}^{2}=0.18, \mathrm{p}=0.009\right)$. However, MO-related additional changes accounted much less than LBM for the relationships between $\mathrm{AOD}_{\text {gly }}$ and blood markers.

Conclusion: The results challenge previous reports of maturation-related differences in glycolytic energy turnover and suggest that changes in lean body mass are a more powerful influence than maturity status on glycolytic metabolism during growth.

Keywords: accumulated oxygen deficit, lactate, allometric modelling, maturation, rowing, adolescent 
Glycolytic metabolism during growth

\section{ABBREVIATIONS}

\begin{tabular}{|c|c|}
\hline $\mathrm{AOD}_{\mathrm{gly}}$ & Glycolysis-derived accumulated oxygen deficit \\
\hline $\mathrm{AOD}_{\text {tot }}$ & Total accumulated oxygen deficit \\
\hline APHV & Age at peak height velocity \\
\hline$[\mathrm{BE}]_{\min }$ & Minimal base excess concentration \\
\hline $\mathrm{BF}$ & Body fat \\
\hline $\mathrm{BM}$ & Body mass \\
\hline BMI & Body mass index \\
\hline $\mathrm{CA}$ & Chronological age \\
\hline$\left[\mathrm{HCO}_{3}{ }^{-}\right]_{\min }$ & Minimal bicarbonate concentration \\
\hline $\mathrm{HR}_{\max }$ & Maximal heart rate \\
\hline LBM & Lean body mass \\
\hline$[\mathrm{La}]_{\max }$ & Maximal lactate concentration \\
\hline MO & Maturity offset \\
\hline MPO & Mean power output \\
\hline $\mathrm{pH}_{\min }$ & Minimal pH \\
\hline $\mathrm{PV}_{2 \max }$ & Power at maximal oxygen uptake \\
\hline $\mathrm{OE}_{\text {phostox }}$ & phosphagen- and blood $\mathrm{O}_{2}$ stores-derived oxygen equivalent \\
\hline$\dot{\mathrm{V}} \mathrm{O}_{2 \max }$ & Maximal oxygen uptake \\
\hline
\end{tabular}

74 


\section{Glycolytic metabolism during growth}

\section{INTRODUCTION}

Following their finding of lower muscle lactate concentration resulting from maximal exercise in 13.6year-old boys compared with young men, Eriksson et al. (1971) suggested that glycolytic activity was lower in children than adults. Furthermore, a lower activity level of muscle phosphofructokinase was found in 11- to 13year-old boys as compared with 17- to 58-year-old adults (Eriksson et al. 1973; Gollnick et al. 1972). Other studies also reported lower glycolytic enzyme activities (lactate dehydrogenase, aldolase, pyruvate kinase) in 3to 17-year-old children compared with 29- to 54-year-old adults (Berg et al. 1986; Kaczor et al. 2005). In addition, considering the significant positive relationships between testicular volume index and exercise-induced muscle lactate accumulation (Eriksson et al. 1971) and between salivary/serum testosterone concentration and peak blood lactate responses, some authors supported the contention that glycolysis is dependent on maturity status (Falgairette et al. 1991; Fellmann et al. 1988)

However, conclusions from early studies of the potential immaturity of glycolytic activity before puberty must be interpreted cautiously, as these studies were not systematically designed to test the effects of maturation and employed small sample numbers with a lack of continuum throughout the maturation process. In metabolic studies, children were mostly categorised as pre-pubertal and post-pubertal and issues related to the effect of maturation during the circumpubertal period have not been comprehensively addressed (Ratel et al. 2002). Also, early metabolic studies did not integrate dimensional changes into data interpretation from childhood into adolescence. Yet, scientific evidence highlighted the importance of total working muscle mass and muscle power output on lactate production in humans (Jensen-Urstad et al. 1994). In mammals, it has been also shown that activities of enzymes functioning in anaerobic glycogenolysis (glycogen phosphorylase, pyruvate kinase and lactate dehydrogenase) increase with increasing body mass (Emmett and Hochachka 1981). Moreover, while nonoxidative energy supply assessed by the accumulated oxygen deficit (AOD) was found to be positively associated with muscle mass involved during exercise (Bangsbø et al. 1993), it was also found to be correlated to the quantity of lactate accumulated after all-out exercise in adult rowers (Maciejewski et al. 2013) and muscle lactate concentration following maximal exercise in pubertal children (Eriksson et al. 1971).

This suggests that there might be a dimensional effect on glycolysis-derived accumulated oxygen deficit $\left(\mathrm{AOD}_{\mathrm{gly}}\right)$, metabolic by-products accumulation and their interrelation throughout growth, but this remains to be proven.

Taken together, the lower blood metabolic disturbances (i.e., lower blood lactate accumulation and higher $\mathrm{pH}$ ) resulting from high-intensity exercise in young children (Ratel et al. 2002) could be related to their 


\section{Glycolytic metabolism during growth}

lower glycolytic energy supply or reduced AOD gly (Carlson and Naughton 1993) owing to their smaller body dimensions, e.g., lean body mass (LBM). Such arguments suggest that with LBM accounted for there might not be significant maturation-related differences in glycolytic energy turnover between pre-pubertal, mid-pubertal and post-pubertal children, contrary to what has been previously reported (Eriksson et al. 1971). However, direct evidence showing the respective influence of LBM and maturity status on the differences in AOD $_{\text {gly }}$ and the potentially associated blood metabolic disturbances (i.e., lactate, $\mathrm{pH}$ ) between pre-, mid- and post-pubertal children is still lacking.

Therefore, the purpose of the present study was to determine whether the increase in glycolytic metabolism during growth, assessed by $\mathrm{AOD}_{\text {gly }}$ and blood metabolic responses (i.e., increased blood lactate accumulation and decreased $\mathrm{pH}$ ) is principally influenced by concomitant changes in LBM. We hypothesise that the lower blood lactate accumulation and higher $\mathrm{pH}$ resulting from high-intensity exercise in younger children could be explained by a reduced amount of energy released from glycolysis (i.e., AOD $_{\text {gly }}$ ) owing to a smaller LBM rather than maturity status. A proportional allometric modelling approach will be used to check our assumptions by controlling for the effects of LBM and maturity status.

\section{MATERIALS AND METHODS}

\section{Participants}

Thirty-six male competitive rowers aged from 11 to 17 years volunteered to participate in the present study. All participants trained three to six times per week (i.e., two to four "on-water" training sessions and one to two physical training sessions) preceding the experiments. None of the participants had a family history of cardiovascular disease or was using any medication. The present study was approved by an institutional ethics review board (Comité d'Éthique pour la Recherche en Sciences et Techniques des Activités Physiques et Sportives - CERSTAPS, $n^{\circ}$ 2017-29-11-20) and conformed to the standards of use of human participants in research as outlined in the Sixth Declaration of Helsinki. The participants were informed of the experimental procedures and gave their written assent before any testing was conducted. In addition, the written informed consent was obtained from the parents or legal guardians of the participants.

\section{Experimental procedure}

Volunteers were tested in two experimental sessions separated by at least 48 hours. Participants were instructed not to undertake any strenuous activity during the 24 hours preceding each session. The first session 


\section{Glycolytic metabolism during growth}

135

136

137

138

139

140

141

142

143

144

145

146

147

148

149

150

151

152

153

154

155

156

157

was dedicated to gathering participants' physical characteristics (anthropometric measurements, body

composition and maturity status) and maximal oxygen uptake $\left(\mathrm{VO}_{2 \max }\right)$ assessment. During the second session, the volunteers performed a 60-s all-out test. The two exercise sessions were carried out on a rowing ergometer (Model D, Concept2, Morrisville, VT, USA). The young rowers were fully familiarised with the equipment. The computer of the ergometer continuously delivered the power output and stroke rates (in $\mathrm{W}$ and $\mathrm{min}^{-1}$, respectively). The resistance factor was set by the investigators between 100 and 130 according to age and the expertise level of young rowers. The same resistance factor was kept for both tests. Verbal encouragement was systematically provided by the investigators during each exercise session.

\section{Experimental measurements}

Session 1: Anthropometric characteristics and body composition. Body mass (BM in $\mathrm{kg}$ ) was measured using a digital weight scale with a precision of $\pm 0.01 \mathrm{~kg}$ (Seca 899, Seca, Germany). Standing height (in m) was assessed using a stadiometer with a precision of $\pm 1 \mathrm{~mm}$ (Seca 213, Seca, Germany). Sitting height (in m) was also measured with the stadiometer while the participants sat on the floor with their back against a wall. Body mass index (BMI) was subsequently calculated using a standard formula, as follows: mass divided by height squared (in $\mathrm{kg} \cdot \mathrm{m}^{-2}$ ). Skinfold thicknesses were measured in triplicate at the triceps and subscapular sites using a Harpenden calliper (British Indicators Ltd, St Albans, UK). The measurements were taken by the same experienced investigator on the right side of the body to reduce variability in the results. Body fat percentage (BF in \%) and lean body mass (LBM in kg) were determined using Slaughter's et al. equations (Slaughter et al. 1988). These equations are specific to sex, ethnicity and maturity status, and are recommended for assessing BF and LBM in children 8-18 years of age.

Maturity status. Maturity offset (MO in years) was determined to assess somatic maturity (i.e., years to (from) age at peak height velocity, APHV) by using chronological age (CA), BM, standing height and sitting height. Its calculation was based on sex-specific regression equations according to the method proposed by Mirwald et al. (2002). Children were categorised by their maturity status (pre-, mid- or post-PHV) into discrete bands based on their MO (pre-PHV: <-1, mid-PHV: - 1 to +1 , post-PHV: > 1) (Birat et al. 2020).

Maximal oxygen uptake test. Each participant performed a progressive test to exhaustion to determine maximal $\mathrm{O}_{2}$ uptake $\left(\dot{\mathrm{VO}}_{2 \max }\right.$ in $\left.\mathrm{L} \cdot \mathrm{min}^{-1}\right)$. The initial power was set between 40 and $80 \mathrm{~W}$ during the first five minutes and 


\section{Glycolytic metabolism during growth}

165 the power was incremented by 10-30 W every three minutes according to age and the expertise level of

166 participants (Maciejewski et al. 2013). Arterialised capillary blood samples (20 $\mu \mathrm{L})$ were taken from the earlobe at rest and every step to measure the time course of blood lactate concentration. Whole blood lactate concentrations ([La] in $\mathrm{mmol} \cdot \mathrm{L}^{-1}$ ) were determined enzymatically using a Biosen C-Line Clinic lactate analyser (EFK Diagnostics GmbH, Barleben, Germany).

170 Oxygen uptake, carbon dioxide output and ventilation were continuously monitored with a breath-by-breath analyser (Quark CPET, Cosmed, Italy). Heart rate was continuously recorded with a heart rate monitor (HRM-

172 Dual, Garmin, Kansas, USA). The mechanical power output corresponding to $\dot{\mathrm{VO}}_{2 \max }\left(\mathrm{PV}_{2 \max }\right.$ in W) and the

173 linear relationship between $\dot{\mathrm{VO}}_{2}$ and power output were also assessed. $\dot{\mathrm{V}} \mathrm{O}_{2 \max }$ was considered to be reached

174 during the last step when at least two of the following criteria were met: (i) $\dot{\mathrm{O}}_{2}$ levelling-off, (ii) maximal respiratory exchange ratio $\left(\mathrm{RER}_{\max }\right) \geq 1.1$, (iii) maximal $\mathrm{HR}\left(\mathrm{HR}_{\max }\right) \geq 95 \%$ of the age-predicted $\mathrm{HR}_{\max }(208.6-$ $0.7 \cdot$ age) (age in years) (Shargal et al. 2015) and (iv) blood lactate concentration higher than $8 \mathrm{mmol} \cdot \mathrm{L}^{-1}$. sprints (10-s) in the last five minutes, all participants performed a 60-s all-out test. This test was followed by a 10-min sitting recovery. Cardio-respiratory parameters were continuously measured using a breath-by-breath analyser (Quark CPET, Cosmed, Italy). Capillary arterialised blood samples $(80 \mu \mathrm{L})$ were drawn from the

182 earlobe and collected after warm-up and at $1,3,5$, and 8 min post-exercise to measure the time course of $\mathrm{pH}$, and 183 lactate $\left([\mathrm{La}]\right.$ in $\left.\mathrm{mmol} \cdot \mathrm{L}^{-1}\right)$, bicarbonate $\left(\left[\mathrm{HCO}_{3}^{-}\right]\right.$in $\left.\mathrm{mmol} \cdot \mathrm{L}^{-1}\right)$ and base-excess $\left([\mathrm{BE}]\right.$ in $\left.\mathrm{mmol} \cdot \mathrm{L}^{-1}\right)$

184 concentrations. Blood [La] was determined enzymatically using the same lactate analyser as in the first session while $\mathrm{pH},\left[\mathrm{HCO}_{3}^{-}\right]$and $[\mathrm{BE}]$ were measured by direct potentiometry using an i-STAT® handheld analyser

186 (Abbott Point of Care, Princeton, USA) immediately after collection. The maximal lactate concentration ([La] $]_{\max }$ 187 in mmol $\left.\cdot \mathrm{L}^{-1}\right)$, the minimal $\mathrm{pH}$ value $\left(\mathrm{pH}_{\min }\right)$, and the minimal concentrations of bicarbonate $\left(\left[\mathrm{HCO}_{3}\right]_{\min }\right.$ in $\left.188 \mathrm{mmol} \cdot \mathrm{L}^{-1}\right)$ and base-excess $\left([\mathrm{BE}]_{\min }\right.$ in $\left.\mathrm{mmol} \cdot \mathrm{L}^{-1}\right)$ were identified. Mean power output $(\mathrm{MPO}$ in $\mathrm{W})$ was 189 calculated over the entire test. In addition, total accumulated oxygen deficit ( $\mathrm{AOD}_{\text {tot }}$ in $\mathrm{L} \mathrm{O}_{2}$ Eq.) and glycolysis190 derived accumulated oxygen deficit ( $\mathrm{AOD}_{\mathrm{gly}}$ in $\mathrm{L} \mathrm{O}_{2}$ Eq.) were individually determined according to the 191 procedures described below. 


\section{Glycolytic metabolism during growth}

195

196

197

198

199

200

201

202

203

204

205

206

207

208

209

210

211

212

213

214

215

216

217

218

219

220

221

222

223

224

\section{Measurements and calculations}

Total accumulated oxygen deficit. $\mathrm{AOD}_{\text {tot }}$ was determined by subtracting accumulated $\mathrm{O}_{2}$ uptake (the measured $\mathrm{O}_{2}$ uptake integrated over time) from accumulated $\mathrm{O}_{2}$ demand (the estimated $\mathrm{O}_{2}$ demand integrated over time). In accordance with Green and Dawson (1996), oxygen demand was extrapolated using the equation of the $\mathrm{V}_{2}-$ power output linear regression obtained in session 1 and considering the individual value of $\dot{\mathrm{V}} \mathrm{O}_{2 \text { rest }}$ (i.e., $\dot{\mathrm{V}} \mathrm{O}_{2}$ measured during three min before the test) for a power output equal to $0 \mathrm{~W}$. Because the present study concerned all-out exercise, $\mathrm{O}_{2}$ demand was calculated from instantaneous power output (recorded stroke by stroke) rather than mean power output sustained during exercise (i.e., MPO) as initially proposed by Medbø et al. (1988).

Glycolysis-derived AOD. $\mathrm{AOD}_{\mathrm{gly}}$ was assessed by subtracting phosphagen- and blood $\mathrm{O}_{2}$ stores-derived oxygen equivalent $\left(\mathrm{OE}_{\text {phostox }}\right)$ to $\mathrm{AOD}_{\text {tot }}$. $\mathrm{OE}_{\text {phostox }}$ was evaluated from the integral of the fast component of $\mathrm{VO}_{2}$ recovery kinetic using a bi-exponential 4-parameter model, as previously done (Beneke et al. 2002; di Prampero 1981):

where $A_{1}, A_{2}$ (in L·min ${ }^{-1}$ ) are the amplitudes of fast and slow components, respectively; $\tau_{1}$ and $\tau_{2}$ the corresponding time constants (in $\mathrm{min}$ ), and $\mathrm{y}_{0}\left(\right.$ in $\mathrm{L} \cdot \mathrm{min}^{-1}$ ) the asymptotic resting $\dot{\mathrm{VO}}_{2}$ at time $\rightarrow \infty$.

Fitted $\dot{\mathrm{V}} \mathrm{O}_{2}$ data were then integrated over time from the start of recovery to $\tau_{1}$ value, and resting $\dot{\mathrm{V}}_{2}$ value integrated over the same time was subtracted.

Allometric modelling procedures. Allometric approach is used to remove any dimensional effect on parameters, and thereby allow fair comparisons between populations of different body dimensions and compositions. As the large range of LBM in the studied population (30.1 to $78.7 \mathrm{~kg}$ ) may have influenced the capacity to supply glycolytic nonoxidative energy (i.e., $\mathrm{AOD}_{\text {gly }}$ ), we further investigated the influence of $\mathrm{LBM}$ on the relationships between $\mathrm{AOD}_{\text {gly }}$ and extreme blood metabolic responses (i.e., $[\mathrm{La}]_{\max }, \mathrm{pH}_{\min },\left[\mathrm{HCO}_{3}^{-}\right]_{\min }$ and $[\mathrm{BE}]_{\min }$ ), by analysing these relationships with LBM as scaling factor through an allometric modelling procedure. The allometric relationship obtained between LBM and $\mathrm{AOD}_{\text {gly }}$ was based on the general allometric equation (Nevill et al. 1992): 
Glycolytic metabolism during growth

$$
A O D_{\text {gly }}=a_{1} \cdot L B M^{b_{1}} \quad \text { (Eq. 2) }
$$

where $a_{l}$ is the proportionality coefficient and $b_{l}$ the scaling factor associated with LBM. The resultant power

function ratio $\mathrm{AOD}_{\mathrm{gly}} \cdot \mathrm{LBM}^{b_{1}}$ is allegedly free from the confounding influence of LBM. The statistical approach

to allometry is to use a simple logarithmic transformation as follows:

$$
\log \left(A O D_{\text {gly }}\right)=b_{1} \cdot \log (L B M)+\log \left(a_{1}\right)
$$

where $b_{1}$ is the slope of the linear regression. This slope is calculated by regression analysis, where $b_{1}$ in the regression output is equal to the scaling factor and the inverse $\log$ of $\log a_{l}$ is equivalent to the constant $a_{l}$ in the Eq. 2.

If this first methodological approach totally accounts for the effects of LBM on $\mathrm{AOD}_{\mathrm{gly}}$, it is important to underline that LBM could also be influenced by individual maturity status. As a result, we also used the multiplicative allometric model proposed by Nevill and Holder (1994) including the maturity indicator as a second factor within an exponential term in addition to the LBM component. This procedure takes into account both LBM and the effect of MO on LBM on $\mathrm{AOD}_{\mathrm{gly}}$ as follows:

$$
\text { AODgly }=L B M^{b_{2}} \cdot \exp \left(a_{2}+c \cdot M O\right)
$$

where $a_{2}$ is the proportionality coefficient, $b_{2}$ and $c$ are the scaling factors associated with LBM and MO, respectively.

The statistical approach to allometry is to use a multiple logarithmic transformation (as previously done by

248 Carvalho et al. 2012), as follows:

$$
\log \left(A O D_{g l y}\right)=b_{2} \cdot \log (L B M)+a_{2}+c \cdot M O
$$
regression analysis where $b_{2}$ and $c$ are equal to the scaling factors and the inverse $\log$ of $\log a_{2}$ is equivalent to the constant $a_{2}$ in Eq. 4 . 
Glycolytic metabolism during growth

\section{Statistical analysis}

256 Analyses were performed using OriginPro 2020 software (OriginLab, Massachusetts, USA). Descriptive statistics were expressed as mean \pm standard deviation (SD) by maturity groups (pre, mid, post). Differences between maturity groups were analysed using the non-parametric Kruskal-Wallis test. Mann-Whitney test was completed for pairwise comparisons when the Kruskal-Wallis test revealed a significant effect. Linear regression models between $\mathrm{MO}, \mathrm{LBM}, \mathrm{AOD}_{\mathrm{gly}}$, and blood parameters (i.e., $[\mathrm{La}]_{\max }, \mathrm{pH}_{\min },\left[\mathrm{HCO}_{3}^{-}\right]_{\min }$ and $[\mathrm{BE}]_{\min }$ ) were fitted by the least-squares method. The squared Bravais-Pearson correlation coefficients $\left(\mathrm{r}^{2}\right)$ of these linear regression models were calculated. The statistical significance level was set at 5\% (i.e. $\mathrm{p}<0.05$ ).

\section{3}

\section{RESULTS}

Participants' physical and physiological characteristics

266 The physical characteristics and aerobic fitness of participants are detailed by maturity groups in Table 1. CA, MO, standing height, BM, BMI, LBM, $\dot{\mathrm{VO}}_{2 \max }\left(\mathrm{L} \cdot \mathrm{min}^{-1}\right)$ and $\mathrm{PVO}_{2 \max }$ significantly increased while $\mathrm{BF}$ significantly decreased from the pre-PHV to post-PHV group $(\mathrm{p}<0.001)$.

\section{*Table 1 around here*}

60-s all-out test

273 Mechanical and physiological parameters obtained from the 60-s all-out test (i.e., $\mathrm{MPO}, \mathrm{AOD}_{\mathrm{tot}}, \mathrm{AOD}_{\mathrm{gly}}$,

$\mathrm{OE}_{\text {phostox }},[\mathrm{La}]_{\max }, \mathrm{pH}_{\min },\left[\mathrm{HCO}_{3}^{-}\right]_{\min },[\mathrm{BE}]_{\min }$ ) are detailed by maturity groups in Table $2 . \mathrm{MPO}, \mathrm{AOD}_{\mathrm{tot}}, \mathrm{AOD}_{\mathrm{gly}}$

$275 \mathrm{OE}_{\text {phostox }}$, and $[\mathrm{La}]_{\max }$ significantly increased while $\mathrm{pH}_{\min },\left[\mathrm{HCO}_{3}^{-}\right]_{\min }$ and $[\mathrm{BE}]_{\min }$ significantly decreased after the 60-s all-out exercise from the pre-PHV to post-PHV group $(\mathrm{p}<0.001)$.

Allometric modelling exponents

281 Allometric scaling exponents $a_{1}$ and $b_{1}$ obtained by the simple procedure (i.e., Eq. 2) were -2.40 and 1.60, respectively. Allometric scaling exponents $a_{2}, b_{2}$ and $c$ obtained from the multiple procedure (i.e., Eq. 4) were $3.96,1.19$ and 0.08 , respectively. 
Glycolytic metabolism during growth

\section{Correlations between variables}

Relationships between metabolic responses, MO and LBM are displayed in Table 3. AOD $\mathrm{gly}_{\mathrm{y}}$, [La $]_{\max }, \mathrm{pH}_{\min }$, $\left[\mathrm{HCO}_{3}{ }^{-}\right]_{\min }$ and $[\mathrm{BE}]_{\min }$ were significantly correlated to $\mathrm{MO}$ and LBM $(\mathrm{p}<0.001$ for all) (Table 3).

*Table 3 around here* addition, $[\mathrm{La}]_{\max }\left(\mathrm{r}^{2}=0.75, \mathrm{p}<0.001\right), \mathrm{pH}_{\min }\left(\mathrm{r}^{2}=0.77, \mathrm{p}<0.001\right),\left[\mathrm{HCO}_{3}\right]_{\min }\left(\mathrm{r}^{2}=0.69, \mathrm{p}<0.001\right)$ and $[\mathrm{BE}]_{\min }\left(\mathrm{r}^{2}=0.74, \mathrm{p}<0.001\right)$ were highly correlated to $\mathrm{AOD}_{\text {gly }}$ (Figures 1A, 1B, 1C, 1D, respectively). However, when $\mathrm{AOD}_{\mathrm{gly}}$ was scaled for $\mathrm{LBM}^{1.60}$ the determination coefficients of the relationships with blood markers drastically decreased by three to four times $\left([\mathrm{La}]_{\max }: \mathrm{r}^{2}=0.24, \mathrm{p}=0.02 ; \mathrm{pH}_{\min }: \mathrm{r}^{2}=0.30, \mathrm{p}<0.001 ;\left[\mathrm{HCO}_{3}\right]_{\min }\right.$ : $\left.\mathrm{r}^{2}=0.19, \mathrm{p}=0.008 ;[\mathrm{BE}]_{\min }: \mathrm{r}^{2}=0.18, \mathrm{p}=0.009\right)$ (Figures $1 \mathrm{E}, 1 \mathrm{~F}, 1 \mathrm{G}, 1 \mathrm{H}$, respectively). Furthermore, by considering the additional effect of MO on LBM, the correlation coefficients between $\mathrm{AOD}_{\mathrm{gly}}$ and blood markers became even lower $\left([\mathrm{La}]_{\max }: \mathrm{r}^{2}=0.12, \mathrm{p}=0.037 ; \mathrm{pH}_{\min }: \mathrm{r}^{2}=0.18, \mathrm{p}=0.009 ;\left[\mathrm{HCO}_{3}{ }^{-}\right]_{\min }: \mathrm{r}^{2}=0.11, \mathrm{p}=0.051\right.$; $\left.[\mathrm{BE}]_{\min }: \mathrm{r}^{2}=0.10, \mathrm{p}=0.061\right)($ Figures $1 \mathrm{I}, 1 \mathrm{~J}, 1 \mathrm{~K}, 1 \mathrm{~L}$, respectively).

\section{DISCUSSION}

The present study aimed to investigate (i) how glycolytic metabolism assessed by accumulated oxygen deficit $\left(\mathrm{AOD}_{\mathrm{gly}}\right)$ and blood metabolic responses (i.e., lactate and $\left.\mathrm{pH}\right)$ changes during growth and (ii) how concomitant changes in lean body mass (LBM) influence $\mathrm{AOD}_{\text {gly }}$ and its relationship with lactate accumulation and $\mathrm{pH}$ reduction. The main results were consistent with our hypotheses since (i) AOD $_{\text {gly }}$ and blood metabolic responses concurrently increased with maturity status (MO) and lean body mass (LBM), and were correlated, and (ii) concomitant changes in LBM accounted much more than maturity status for $\mathrm{AOD}_{\text {gly }}$ and its relationship with lactate accumulation and $\mathrm{pH}$ reduction. The results indicate that with $\mathrm{LBM}$ accounted for there may not be significant maturation-related differences in glycolytic energy turnover, contrary to what has been previously mentioned.

In the present study, $\mathrm{MO}$ and LBM highly accounted for the increment of $\mathrm{AOD}_{\mathrm{gly}}(71 \%$ and $61 \%$, respectively (Table 3). This finding is consistent with previous cross-sectional studies showing that (i) total AOD 


\section{Glycolytic metabolism during growth}

is significantly lower in children than adolescents and adults during high-intensity exercise (Carlson and

316 Naughton 1993; Naughton et al. 1997) and (ii) the kinetics of $\mathrm{O}_{2}$ uptake at the onset of high-intensity exercise

317 are faster in children compared with adults (Armon et al. 1991). The results suggest that prepubertal children

318 may adapt their oxidative metabolism faster than their older counterparts to meet the higher energy requirements

319 and, hence, have a lower need for nonoxidative metabolism at the onset of high-intensity exercise. However, the

320 present data indicate for the first time a progressive increase in glycolysis-specifically derived AOD from

321 childhood into adolescence and this is associated with LBM and MO (Table 3).

The blood metabolic responses (i.e., $[\mathrm{La}]_{\max }, \mathrm{pH}_{\min },\left[\mathrm{HCO}_{3}{ }^{-}\right]_{\min },[\mathrm{BE}]_{\min }$ ) were also highly associated with $\mathrm{LBM}$ and higher $\mathrm{pH}$ in prepubertal boys than men, either after a Wingate test (Hebestreit et al. 1996) or following repeated cycle sprints (Ratel et al. 2002). However, in the present study, the metabolic stress elicited by highintensity exercise during rowing was higher than from other forms of exercise in children. Indeed, in previous studies, high-intensity exercises yielded post-exercise peak blood [La] from 7.7 to $8.4 \mathrm{mmol} \cdot \mathrm{L}^{-1}$ during cycling (Falgairette et al. 1991) or 7.8 to $11.0 \mathrm{mmol} \cdot \mathrm{L}^{-1}$ during running (Paterson et al. 1986) between the ages of 10 and 15 years while data from our population ranged from 10.2 to $15.9 \mathrm{mmol} \cdot \mathrm{L}^{-1}$ (Table 2). Similarly, end-of-exercise blood $\mathrm{pH}$ values of 7.36-7.37 in 10-year-old boys and 7.28 in 15-year-old male adolescents after repeated sprints have been reported (Kappenstein et al. 2015; Ratel et al. 2004) while values obtained in the present study were 7.24 in pre-pubertal boys and 7.13 in post-pubertal boys. Such discrepancies could be ascribed to differences in

334 body mass engaged during exercise as blood metabolic responses were found to be highly associated with LBM. 335 Even if the body mass is not supported in rowing, it involves a greater muscle mass during exercise [about $85 \%$ 336 of the total muscle mass (Mader et al. 1988; Maciejewski et al. 2013)], than other modalities of exercise such as 337 cycling [about 25 to 30\% of body mass (Gastin 2001)], or running (Bangsbø et al. 1993). The greater muscle 338 mass involved in rowing could elicit a greater glycolytic energy supply and thereby a higher blood lactate 339 accumulation and $\mathrm{pH}$ or $\left[\mathrm{HCO}_{3}{ }^{-}\right]$reduction (Bangsbø et al. 1993; Saltin 1990). However, direct evidence 340 showing the effect of exercise mode on blood metabolic responses during high-intensity exercise during growth 341 and maturation is still lacking. 


\section{Glycolytic metabolism during growth}

growth. This finding is novel as no previous studies have analysed the relationships between the (total and glycolysis-derived) accumulated $\mathrm{O}_{2}$ deficit and blood acid-base disturbance in response to high-intensity exercise during growth. Only Naughton et al. (1997) evaluated total AOD and plasma markers of anaerobic metabolism (lactate, $\mathrm{pH}$, ammonium) during treadmill runs at $120-130 \%$ of $\dot{\mathrm{V}}_{2 \max }$ in 14-year-old trained male and female adolescents but these authors did not establish any relationship between the parameters. In adults, previous studies have provided contradictory data on these relationships; some authors failed to find significant correlations between $[\mathrm{La}]_{\max }$ and total AOD in elite athletes (Bangsbø et al. 1993) while others found an association between the quantity of lactate accumulated and total AOD in well-trained rowers (Maciejewski et al. 2013). This discrepancy could be related to methodological issues given that $[\mathrm{La}]_{\max }$ reflects the balance

354 between production and removal of lactate at the time of measurement while the quantity of lactate accumulated is an estimate of total production considering the quantity of lactate removed from the body. Although in the present study the quantity of lactate accumulated was not assessed and [La $]_{\max }$ was measured, $\mathrm{AOD}_{\mathrm{gly}}$ highly accounted for the variance of blood lactate concentration (i.e., 75\%). This was also the case for the other blood metabolic responses (i.e., $77 \%, 69 \%$ and $74 \%$ for $\mathrm{pH}_{\min },\left[\mathrm{HCO}_{3}{ }^{-}\right]_{\min }$ and $[\mathrm{BE}]_{\min }$, respectively). positive (1.60), supporting the notion that $\mathrm{AOD}_{\text {gly }}$ increased with LBM. However, this allometric exponent was clearly higher than the coefficients usually calculated between body mass and $\dot{\mathrm{V}}_{2 \max }$ (e.g., 0.75) (Armstrong and Welsman 2019; Nevill et al. 1992) or between LBM and $\dot{\mathrm{VO}}_{2 \max }$ (i.e., 1.13) in the present study (Table 1). This allometric exponent is consistent with the high body size allometric exponents reported during highintensity exercises, as for instance in adolescent rowers during a 30-s all-out test (i.e., 1.24) (Maciejewski et al. 2016). Consequently, body size exponents could be higher in anaerobic vs aerobic exercise conditions, and anaerobic metabolic responses could be greater in heavier than lighter individuals, as it is the case for $\mathrm{AOD}_{\mathrm{gly}}$ in

367 the present study. This could be ascribed to additional anaerobic energy required to move (lean) body mass during all-out exercise compared to aerobic exercise, particularly in heavier individuals. relationship with blood parameters. When the effect of LBM was considered in the relationships between $\mathrm{AOD}_{\text {gly }}$ and $[\mathrm{La}]_{\max }, \mathrm{pH}_{\min },\left[\mathrm{HCO}_{3}^{-}\right]_{\min }$ and $[\mathrm{BE}]_{\min }$, the coefficients of determination drastically decreased by 373 three to four times with respect to those obtained from absolute $\mathrm{AOD}_{\text {gly }}$ values (Figures $1 \mathrm{E}, 1 \mathrm{~F}, 1 \mathrm{G}, 1 \mathrm{H}$ ). The 


\section{Glycolytic metabolism during growth}

375 determination decreased to a lesser extent (Figures 1I, 1J, 1K, 1L). Taken together, this indicates that there

376 would be an associated-cumulative effect of maturity status in addition to the significant influence of LBM on

$377 \mathrm{AOD}_{\mathrm{gly}}$ and its relationship with blood metabolic responses. However, LBM could be considered as the main

378 influence on these metabolic changes.

379

380

381

382

383

384

385

386

387

Several considerations should be mentioned in this study. The number of years the rowers have been training prior to the study was different between younger and older participants. However, this difference should not affect the conclusions of the present study since aerobic fitness evaluated from $\dot{\mathrm{V}} \mathrm{O}_{2 \max }$ normalised for LBM $^{1.13}$ was not significantly different between the maturity status groups (Table 1). Moreover, although validation studies of maturity offset indicated several limitations for the prediction of biological maturation (Fransen et al. 2018), the level of accuracy of this method was found to be sufficient to assign a maturational classification with a standard error of 0.5 years between the ages of 8 and 16 years (Mirwald et al. 2002). If we had used the Tanner staging criteria based on pubic hair and testicular volume, we could not have analysed the effect of maturation on $\mathrm{AOD}_{\mathrm{gly}}$ and its relationship with blood markers from the allometric method, as these criteria are categorical variables while maturity offset is a continuous discrete variable. Another point of consideration is that girls were not evaluated. Sex-related differences on $\mathrm{AOD}_{\mathrm{gly}}$ and blood responses could be expected during puberty, as body composition (whole-body lean vs fat mass) changes significantly over this period between males and females (Van Praagh and Dore 2002), but this remains to be proven.

In conclusion, $\mathrm{AOD}_{\mathrm{gly}}$ and blood metabolic responses in boys linearly increased with maturity status and lean body mass. Lactate accumulation and $\mathrm{pH}$ reduction resulting from high-intensity exercise were found to be highly associated with the amount of energy released from glycolysis. Changes in lean body mass during growth accounted much more than maturity status for glycolysis-derived accumulated oxygen deficit and its relationship with lactate accumulation and $\mathrm{pH}$ reduction. The results challenge previous reports of maturationrelated differences in glycolytic energy turnover and suggest that changes in lean body mass are a more powerful influence than maturity status on glycolytic metabolism during growth.

In the occupational, exercise or sporting context, the results of the present study may prove relevant since it has often been considered that anaerobic glycolysis is immature in pre-pubertal children (Eriksson et al. 1971) and it is, therefore, useless to propose physical activities soliciting the glycolytic process to improve 


\section{Glycolytic metabolism during growth}

405 anaerobic capacity before puberty (Ratel and Martin 2012). This work could lead physical educators, teachers,

406 students and coaches who have to train young people to reconsider these conclusions, as dimensional changes

407 could mainly account for glycolytic activity during growth. However, this work needs to be pursued in girls,

408 since body composition (whole-body lean vs fat mass) changes significantly during growth between boys and

409 girls (Tanner et al. 1981), and lean body mass could act differently on glycolytic metabolism between both

410 sexes. 
Glycolytic metabolism during growth

\section{REFERENCES}

Armon Y, Cooper DM, Flores R, Zanconato S, Barstow TJ (1991) Oxygen uptake dynamics during high-intensity exercise in children and adults J Appl Physiol 70:841-848 doi:10.1152/jappl.1991.70.2.841

Armstrong N, Welsman JO (2019) Sex-Specific Longitudinal Modeling of Short-Term Power in 11- to 18-Year-Olds Med Sci Sports Exerc 51:1055-1063 doi:10.1249/MSS.0000000000001864

Bangsbø J, Michalsik L, Petersen A (1993) Accumulated O2 deficit during intense exercise and muscle characteristics of elite athletes Int J Sports Med 14:207-213 doi:10.1055/s-20071021165

Beneke R, Pollmann C, Bleif I, Leithauser RM, Hutler M (2002) How anaerobic is the Wingate Anaerobic Test for humans? Eur J Appl Physiol 87:388-392 doi:10.1007/s00421-0020622-4

Berg A, Kim SS, Keul J (1986) Skeletal muscle enzyme activities in healthy young subjects Int J Sports Med 7:236-239 doi:10.1055/s-2008-1025766

Birat A et al. (2020) Effect of Drop Height on Vertical Jumping Performance in Pre-, Circa-, and Post-Pubertal Boys and Girls Pediatr Exerc Sci 32:23-29

Carlson JS, Naughton GA (1993) An examination of the anaerobic capacity of children using maximal accumulated oxygen deficit Pediatr Exerc Sci 5:60-71

di Prampero PE (1981) Energetics of muscular exercise Rev Physiol Biochem Pharmacol 89:143-222 doi:10.1007/bfb0035266

Carvalho HM, Coelho-e-Silva M, Valente-dos-Santos J, Goncalves RS, Philippaerts R, Malina R (2012) Scaling lower-limb isokinetic strength for biological maturation and body size in adolescent basketball players Eur J Appl Physiol 112:2881-2889 doi:10.1007/s00421-011-2259-7

Emmett B, Hochachka PW (1981) Scaling of oxidative and glycolytic enzymes in mammals Respir Physiol 45:261-272

Eriksson BO, Gollnick PD, Saltin B (1973) Muscle metabolism and enzyme activities after training in boys 11-13 years old Acta Physiol Scand 87:485-497 doi:10.1111/j.17481716.1973.tb05415.x

Eriksson BO, Karlsson J, Saltin B (1971) Muscle metabolites during exercise in pubertal boys Acta Paediatr Scand Suppl 217:154-157

Falgairette G, Bedu M, Fellmann N, Van-Praagh E, Coudert J (1991) Bio-energetic profile in 144 boys aged from 6 to 15 years with special reference to sexual maturation Eur J Appl Physiol Occup Physiol 62:151-156

Fellmann N, Bedu M, Spielvogel H, Falgairette G, Van Praagh E, Jarrige JF, Coudert J (1988) Anaerobic metabolism during pubertal development at high altitude J Appl Physiol (1985) 64:1382-1386 doi:10.1152/jappl.1988.64.4.1382

Fransen J et al. (2018) Improving the Prediction of Maturity From Anthropometric Variables Using a Maturity Ratio Pediatr Exerc Sci 30:296-307 doi:10.1123/pes.2017-0009

Gastin PB (2001) Energy system interaction and relative contribution during maximal exercise Sports Med 31:725-741

Gollnick PD, Armstrong RB, Saubert CWt, Piehl K, Saltin B (1972) Enzyme activity and fiber composition in skeletal muscle of untrained and trained men J Appl Physiol 33:312-319 doi:10.1152/jappl.1972.33.3.312

Green S, Dawson BT (1996) Methodological effects on the VO2-power regression and the accumulated O2 deficit Med Sci Sports Exerc 28:392-397

Hebestreit H, Meyer F, Htay H, Heigenhauser GJ, Bar-Or O (1996) Plasma metabolites, volume and electrolytes following 30-s high-intensity exercise in boys and men Eur J Appl Physiol Occup Physiol 72:563-569 
Jensen-Urstad M, Svedenhag J, Sahlin K (1994) Effect of muscle mass on lactate formation during exercise in humans Eur J Appl Physiol Occup Physiol 69:189-195 doi:10.1007/bf01094787

Kaczor JJ, Ziolkowski W, Popinigis J, Tarnopolsky MA (2005) Anaerobic and aerobic enzyme activities in human skeletal muscle from children and adults Pediatr Res 57:331-335 doi:10.1203/01.PDR.0000150799.77094.DE

Kappenstein J, Engel F, Fernandez-Fernandez J, Ferrauti A (2015) Effects of active and passive recovery on blood lactate and blood $\mathrm{pH}$ after a repeated sprint protocol in children and adults Pediatr Exerc Sci 27:77-84 doi:10.1123/pes.2013-0187

Maciejewski H, Bourdin M, Lacour JR, Denis C, Moyen B, Messonnier L (2013) Lactate accumulation in response to supramaximal exercise in rowers Scand J Med Sci Sports 23:585-592 doi:10.1111/j.1600-0838.2011.01423.x

Maciejewski H, Rahmani A, Chorin F, Lardy J, Giroux C, Ratel S (2016) The 1,500-m Rowing Performance is Highly Dependent on Modified Wingate Anaerobic Test Performance in National-Level Adolescent Rowers Pediatr Exerc Sci 28:572-579 doi:10.1123/pes.2015-0283

Mader A, Hartmann U, Hollmann W (1988) Der Einfluß der Ausdauer auf die 6minütige maximale anaerobe und aerobe Arbeitskapazität eines Eliteruderers. In: Rudern. Springer, pp 62-78

Medbø JI, Mohn AC, Tabata I, Bahr R, Vaage O, Sejersted OM (1988) Anaerobic capacity determined by maximal accumulated O2 deficit J Appl Physiol 64:50-60 doi:10.1152/jappl.1988.64.1.50

Mirwald RL, Baxter-Jones AD, Bailey DA, Beunen GP (2002) An assessment of maturity from anthropometric measurements Med Sci Sports Exerc 34:689-694

Naughton GA, Carlson JS, Buttifant DC, Selig SE, Meldrum K, McKenna MJ, Snow RJ (1997) Accumulated oxygen deficit measurements during and after high-intensity exercise in trained male and female adolescents Eur J Appl Physiol Occup Physiol 76:525-531 doi:10.1007/s004210050285

Nevill AM, Holder RL (1994) Modelling Maximum Oxygen Uptake - a Case-Study in Nonlinear Regression Model Formulation and Comparison Appl Statist 43:653-666

Nevill AM, Ramsbottom R, Williams C (1992) Scaling physiological measurements for individuals of different body size Eur J Appl Physiol Occup Physiol 65:110-117

Paterson DH, Cunningham DA, Bumstead LA (1986) Recovery O2 and blood lactic acid: longitudinal analysis in boys aged 11 to 15 years Eur J Appl Physiol Occup Physiol 55:93-99

Ratel S, Duche P, Hennegrave A, Van Praagh E, Bedu M (2002) Acid-base balance during repeated cycling sprints in boys and men J Appl Physiol (1985) 92:479-485 doi:10.1152/japplphysiol.00495.2001

Ratel S, Martin V (2012) Les exercices anaérobies lactiques chez les enfants : la fin d'une idée reçue ? Science \& Sports 27:195-200 doi:10.1016/j.scispo.2011.08.004

Ratel S, Williams CA, Oliver J, Armstrong N (2004) Effects of age and mode of exercise on power output profiles during repeated sprints Eur J Appl Physiol 92:204-210 doi:10.1007/s00421-004-1081-x

Saltin B (1990) Anaerobic capacity: past, present and prospective Biochemistry of exercise VII 21:387-421

Shargal E, Kislev-Cohen R, Zigel L, Epstein S, Pilz-Burstein R, Tenenbaum G (2015) Agerelated maximal heart rate: examination and refinement of prediction equations $\mathrm{J}$ Sports Med Phys Fitness 55:1207-1218 
Glycolytic metabolism during growth

509

510

511

512

513

514

515

516

517
Slaughter MH, Lohman TG, Boileau RA, Horswill CA, Stillman RJ, Van Loan MD, Bemben DA (1988) Skinfold equations for estimation of body fatness in children and youth Hum Biol 60:709-723

Tanner JM, Hughes PC, Whitehouse RH (1981) Radiographically determined widths of bone muscle and fat in the upper arm and calf from age 3-18 years Ann Hum Biol 8:495-517 doi:10.1080/03014468100005351

Van Praagh E, Dore E (2002) Short-term muscle power during growth and maturation Sports Med 32:701-728 
Glycolytic metabolism during growth

518 Table 1: Physical characteristics and aerobic fitness of the different maturity groups $(n=36)($ mean \pm SD).

\begin{tabular}{|c|c|c|c|c|c|c|}
\hline & $\begin{array}{l}\text { Pre-PHV } \\
\quad(n=8)\end{array}$ & \multicolumn{2}{|l|}{$\begin{array}{l}\text { Mid-PHV } \\
(\mathrm{n}=11)\end{array}$} & \multicolumn{3}{|c|}{$\begin{array}{l}\text { Post-PHV } \\
\quad(\mathrm{n}=17)\end{array}$} \\
\hline Chronological age (years) & $12.4 \pm 0.9$ & $13.7 \pm 0.7$ & $* *$ & 16.2 & \pm 0.9 & $* * * \$ \$$ \\
\hline MO (years) & $-1.7 \pm 0.6$ & $0.0 \pm 0.5$ & $* * *$ & 2.2 & \pm 0.6 & $* * * \$ \$$ \\
\hline Standing height $(\mathrm{m})$ & $1.55 \pm 0.09$ & $1.70 \pm 0.05$ & $* *$ & 1.80 & \pm 0.07 & $* * * \$ \$ \$$ \\
\hline $\mathrm{BM}(\mathrm{kg})$ & $43.6 \pm 6.2$ & $60.7 \pm 3.3$ & $* * *$ & 70.5 & \pm 6.8 & $* * * \$ \$$ \\
\hline $\mathrm{BMI}\left(\mathrm{kg} \cdot \mathrm{m}^{-2}\right)$ & $18.0 \pm 1.3$ & $21.0 \pm 1.1$ & $* * *$ & 21.7 & \pm 1.6 & $* * *$ \\
\hline $\mathrm{BF}(\%)$ & $15.1 \pm 4.0$ & $10.6 \pm 5.3$ & & 8.6 & \pm 3.1 & $* * *$ \\
\hline LBM $(\mathrm{kg})$ & $37.0 \pm 5.0$ & $54.4 \pm 4.9$ & $* * *$ & 64.4 & \pm 6.0 & $* * * \$ \$$ \\
\hline$\dot{\mathrm{V}}{ }_{2 \max }\left(\mathrm{L} \cdot \mathrm{min}^{-1}\right)$ & $2.36 \pm 0.43$ & $3.47 \pm 0.55$ & $* * *$ & 4.54 & \pm 0.28 & $* * * \$ \$$ \\
\hline$\dot{\mathrm{V}} \mathrm{O}_{2 \max }\left(\mathrm{mL} \cdot \mathrm{min}^{-1} \cdot \mathrm{LBM}^{-1.13}\right)$ & $40 \pm 5$ & $38 \pm 5$ & & 41 & & \\
\hline $\mathrm{PV}_{2 \max }(\mathrm{W})$ & $126 \pm 24$ & $204 \pm 40$ & $* *$ & 272 & \pm 25 & $* * * \$ \$$ \\
\hline $\mathrm{HR}_{\max }(\mathrm{bpm})$ & $203 \pm 9$ & $206 \pm 7$ & & 200 & \pm 6 & \\
\hline
\end{tabular}

$519 \quad * *: \mathrm{p}<0.01 ; * * *: \mathrm{p}<0.001$ from Pre $;{ }^{\$ \$}: \mathrm{p}<0.001$ from Mid.

520 MO: maturity offset; BM: body mass; BMI: body mass index; BF: body fat percentage; LBM: lean body mass;

$521 \dot{\mathrm{V}} \mathrm{O}_{2 \max }\left(\mathrm{mL} \cdot \mathrm{min}^{-1} \cdot \mathrm{kg}^{-1.13} \mathrm{LBM}\right)$ : $\dot{\mathrm{V}} \mathrm{O}_{2 \max }$ normalized for $\mathrm{LBM}^{1.13}$, allometric exponent was calculated from the

522 following equation: $\log \left(\dot{\mathrm{V}}_{2 \max }\right)=b_{1} \cdot \log (\mathrm{LBM})+\log \left(a_{1}\right)$ (see section Allometric modelling procedures for

523 further explanations); $\mathrm{PV}_{2 \max }$ power corresponding to $\dot{\mathrm{VO}}_{2 \max } ; \mathrm{HR}_{\max }$ : maximal heart rate. 
524 Table 2: Mechanical and physiological parameters obtained from the 60-s all-out test by maturity group $(\mathrm{n}=36)$

525 (mean $\pm \mathrm{SD})$.

526

\begin{tabular}{|c|c|c|c|c|c|c|}
\hline & $\begin{array}{l}\text { Pre-PHV } \\
(\mathrm{n}=8)\end{array}$ & \multicolumn{2}{|l|}{$\begin{array}{l}\text { Mid-PHV } \\
(\mathrm{n}=11)\end{array}$} & \multicolumn{3}{|c|}{$\begin{array}{l}\text { Post-PHV } \\
(\mathrm{n}=17)\end{array}$} \\
\hline MPO (W) & $198 \pm 37$ & $343 \pm 60$ & $* * *$ & 515 & \pm 45 & $* * * \$ \$$ \\
\hline $\mathrm{AOD}_{\text {tot }}\left(\mathrm{L} \mathrm{O}_{2}\right.$ Eq. $)$ & $2.08 \pm 0.45$ & $3.39 \pm 0.60$ & $* * *$ & 5.23 & \pm 0.68 & $* * * \$ \$$ \\
\hline $\mathrm{AOD}_{\text {gly }}\left(\mathrm{L} \mathrm{O}_{2}\right.$ Eq. $)$ & $1.29 \pm 0.33$ & $2.10 \pm 0.49$ & $* * *$ & 3.39 & \pm 0.73 & $* * * \$ \$$ \\
\hline $\mathrm{OE}_{\text {phos+ox }}(\mathrm{L})$ & $0.79 \pm 0.18$ & $1.29 \pm 0.44$ & $* *$ & 1.84 & \pm 0.38 & $* * * \$ \$$ \\
\hline $\mathrm{AOD}_{\mathrm{gly}}\left(\% \mathrm{AOD}_{\mathrm{tot}}\right)$ & $61.7 \pm 6.1$ & $61.9 \pm 11.4$ & & 64.4 & \pm 7.5 & \\
\hline $\mathrm{OE}_{\text {phos+ox }}\left(\% \mathrm{AOD}_{\text {tot }}\right)$ & $38.3 \pm 6.1$ & $38.1 \pm 11.4$ & & 35.6 & \pm 7.5 & \\
\hline$[\mathrm{La}]_{\max }\left(\mathrm{mmol} \cdot \mathrm{L}^{-1}\right)$ & $10.2 \pm 1.5$ & $12.3 \pm 1.1$ & $* *$ & 15.9 & \pm 1.8 & $* * * \$ \$$ \\
\hline $\mathrm{pH}_{\min }(-)$ & $7.24 \pm 0.03$ & $7.21 \pm 0.03$ & $* *$ & 7.13 & \pm 0.04 & $* * * \$ \$$ \\
\hline$\left[\mathrm{HCO}_{3}{ }^{-}\right]_{\min }\left(\mathrm{mmol} \cdot \mathrm{L}^{-1}\right)$ & $13.5 \pm 1.3$ & $11.3 \pm 1.3$ & $* *$ & 8.7 & \pm 1.3 & $* * * \$ \$$ \\
\hline$[\mathrm{BE}]_{\min }\left(\mathrm{mmol} \cdot \mathrm{L}^{-1}\right)$ & $-13.3 \pm 2.0$ & $-16.6 \pm 1.7$ & $* *$ & -20.3 & \pm 1.9 & $* * * \$ \$$ \\
\hline
\end{tabular}

$527 \quad * *: \mathrm{p}<0.01 ; * * *: \mathrm{p}<0.001$ from Pre $; \$ \$ \$$ p $<0.001$ from Mid.

528 MPO: mean power output calculated over the entire test; AOD $_{\text {tot: }}$ total accumulated oxygen deficit; AOD ${ }_{\text {gly }}$ :

529 glycolysis-derived accumulated oxygen deficit; $\mathrm{OE}_{\text {phostox }}$ : phosphagen- and blood $\mathrm{O}_{2}$ stores-derived oxygen

530 equivalent; [La $]_{\max }$ : maximal blood lactate concentration; $\mathrm{pH}_{\min }$ : minimal blood $\mathrm{pH}$; $\left[\mathrm{HCO}_{3}{ }^{-}\right]_{\min }$ : minimal blood

531 bicarbonate concentration; [BE $]_{\min }$ : minimal blood base excess concentration. 
Glycolytic metabolism during growth

532 Table 3: Relationships between metabolic responses, maturity offset and lean body mass $(n=36)$.

\begin{tabular}{lcccccc}
\hline & LBM & $\mathrm{AOD}_{\text {gly }}$ & {$[\mathrm{La}]_{\max }$} & $\mathrm{pH}_{\min }$ & {$\left[\mathrm{HCO}_{3}\right]_{\min }$} & {$[\mathrm{BE}]_{\min }$} \\
& $(\mathrm{kg})$ & $\left(\mathrm{L} \mathrm{O}_{2} \mathrm{Eq}.\right)$ & $\left(\mathrm{mmol} \cdot \mathrm{L}^{-1}\right)$ & $(-)$ & $\left(\mathrm{mmol} \cdot \mathrm{L}^{-1}\right)$ & $\left(\mathrm{mmol} \cdot \mathrm{L}^{-1}\right)$ \\
\hline MO & $\mathrm{r}=0.91$ & $\mathrm{r}=0.84$ & $\mathrm{r}=0.85$ & $\mathrm{r}=-0.78$ & $\mathrm{r}=-0.78$ & $\mathrm{r}=-0.82$ \\
$($ years $)$ & $\mathrm{p}<0.001$ & $\mathrm{p}<0.001$ & $\mathrm{p}<0.001$ & $\mathrm{p}<0.001$ & $\mathrm{p}<0.001$ & $\mathrm{p}<0.001$ \\
\hline LBM & & $\mathrm{r}=0.78$ & $\mathrm{r}=0.78$ & $\mathrm{r}=-0.68$ & $\mathrm{r}=-0.77$ & $\mathrm{r}=-0.79$ \\
$(\mathrm{~kg})$ & & $\mathrm{p}<0.001$ & $\mathrm{p}<0.001$ & $\mathrm{p}<0.001$ & $\mathrm{p}<0.001$ & $\mathrm{p}<0.001$
\end{tabular}

533 MO: maturity offset; LBM: lean body mass; AOD gly: glycolysis-derived accumulated oxygen deficit; [La $]_{\max }$ :

534 maximal blood lactate concentration; $\mathrm{pH}_{\min }$ : minimal blood $\mathrm{pH} ;\left[\mathrm{HCO}_{3}^{-}\right]_{\min }$ : minimal blood bicarbonate

535 concentration; $[\mathrm{BE}]_{\min }$ : minimal blood base excess concentration. 

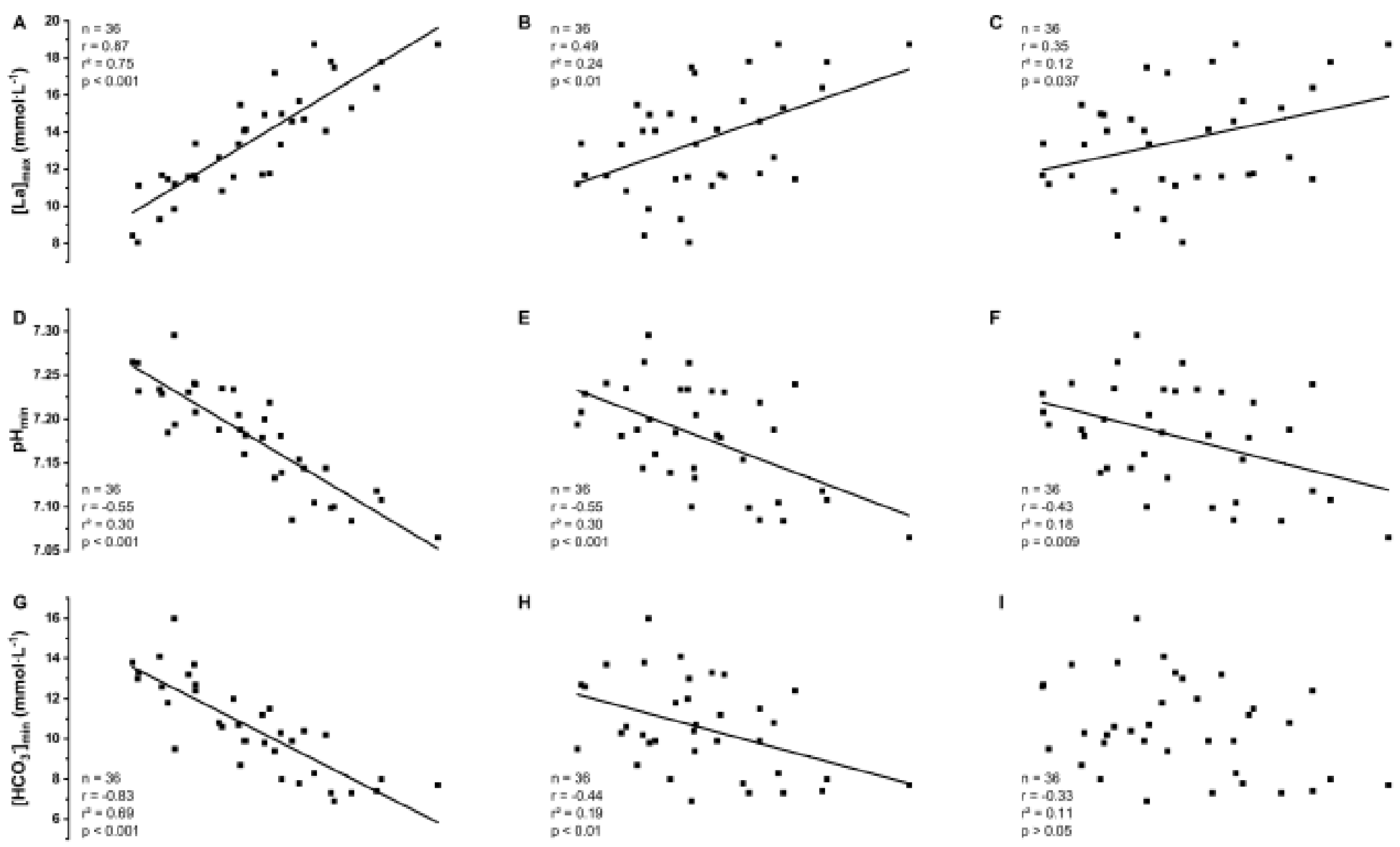

H
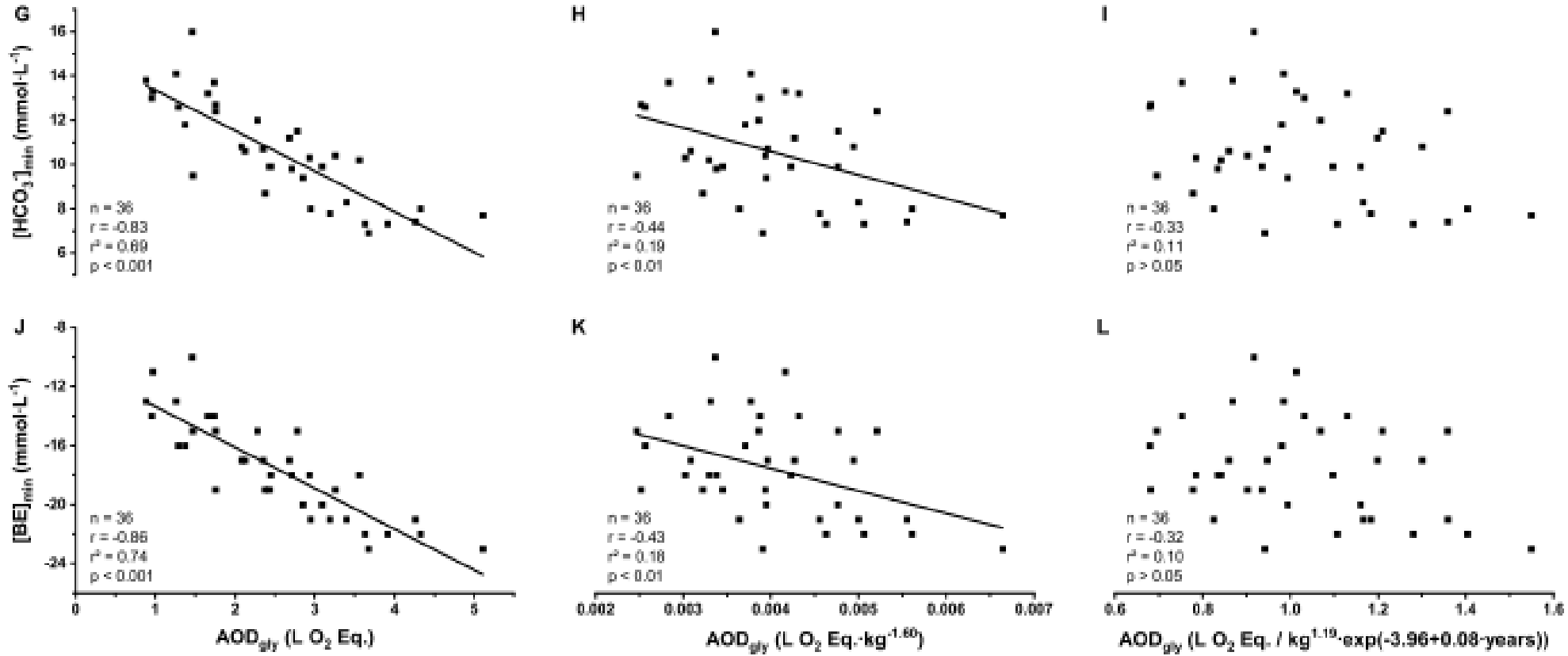
538 Figure 1: Correlations between blood markers and glycolysis-derived accumulated oxygen deficit (AOD $\left.{ }_{\text {gly }}\right)$ 539 expressed in absolute value (Panels A to D), scaled for LBM ${ }^{1.60}$ (Panels E to H) and scaled for LBM + MO (Panels $540 \quad$ I to $\mathrm{L}) ; \mathrm{n}=36$.

$541[\mathrm{La}]_{\max }$ : maximal blood lactate concentration; $\mathrm{pH}_{\min }$ : minimal blood $\mathrm{pH}$; $\left[\mathrm{HCO}_{3}^{-}\right]_{\min }$ : minimal blood bicarbonate 542 concentration; [BE $]_{\min }$ : minimal blood base excess concentration; LBM: lean body mass; MO: maturity offset. 